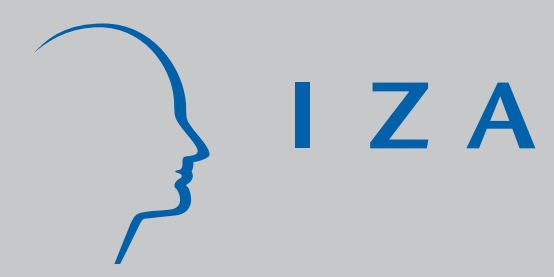

IZA DP No. 4093

The Dynamics of Entrepreneurship: Hysteresis, Business Cycles and Government Policy

Emilio Congregado

Antonio A. Golpe

Simon Parker

March 2009 


\title{
The Dynamics of Entrepreneurship: Hysteresis, Business Cycles and Government Policy
}

\author{
Emilio Congregado \\ University of Huelva \\ Antonio A. Golpe \\ University of Huelva \\ Simon Parker \\ University of Western Ontario \\ and IZA
}

\author{
Discussion Paper No. 4093 \\ March 2009
}

\author{
IZA \\ P.O. Box 7240 \\ 53072 Bonn \\ Germany \\ Phone: +49-228-3894-0 \\ Fax: +49-228-3894-180 \\ E-mail: iza@iza.org
}

\begin{abstract}
Any opinions expressed here are those of the author(s) and not those of IZA. Research published in this series may include views on policy, but the institute itself takes no institutional policy positions.

The Institute for the Study of Labor (IZA) in Bonn is a local and virtual international research center and a place of communication between science, politics and business. IZA is an independent nonprofit organization supported by Deutsche Post Foundation. The center is associated with the University of Bonn and offers a stimulating research environment through its international network, workshops and conferences, data service, project support, research visits and doctoral program. IZA engages in (i) original and internationally competitive research in all fields of labor economics, (ii) development of policy concepts, and (iii) dissemination of research results and concepts to the interested public.
\end{abstract}

IZA Discussion Papers often represent preliminary work and are circulated to encourage discussion. Citation of such a paper should account for its provisional character. A revised version may be available directly from the author. 
IZA Discussion Paper No. 4093

March 2009

\section{ABSTRACT \\ The Dynamics of Entrepreneurship: \\ Hysteresis, Business Cycles and Government Policy}

This paper estimates an unobserved components model to explore the macro dynamics of entrepreneurship in Spain and the US. We ask whether entrepreneurship exhibits hysteresis, defined as a macro dynamic structure in which cyclical fluctuations have persistent effects on the natural rate of entrepreneurship. We find evidence of hysteresis in Spain, but not the US, while in both countries business cycle output variations significantly affect future rates of entrepreneurship. The article discusses implications of the findings for the design of entrepreneurship policies.

JEL Classification: $\quad$ C32, E32, J24

Keywords: hysteresis, unobserved components model, time series models, business cycles, self-employment, entrepreneurship

Corresponding author:

Simon Parker

The University of Western Ontario

1151 Richmond Street North

London, Ontario N6A 3K7

Canada

E-mail: sparker@ivey.uwo.ca 


\section{Introduction}

As national economies continue to feel the forces of globalization, and large companies proceed with outsourcing and downsizing strategies, efforts to find alternative sources of economic growth are intensifying. For many years, governments around the world have regarded entrepreneurship as a promising candidate in this respect. Growing evidence shows that entrepreneurs create disproportionate numbers of innovations and jobs (Acs and Audretsch, 1990; Audretsch, 2003; Haltiwanger, 2006; Baumol, 2007). Entrepreneurship has also been linked with faster rates of economic growth (Audretsch and Keilbach, 2004, 2007; van Stel, Carree and Thurik, 2005).

Many governments have responded to these forces by devising and implementing portfolios of policies to promote entrepreneurship. These policies include loan guarantee schemes; technology-transfer and innovation programs; employment assistance programs; and subsidized provision of business advice and assistance to small firms (Parker, 2009). Loan guarantee schemes insure banks' loans to entrepreneurs; high rates of business failure mean that these schemes typically run at a loss (Parker, 2009, chapter 16). Innovation policies include direct subsidies to innovators; favorable tax treatment for private sector R\&D expenditures; and the provision of seed funds for innovation (Lerner, 1999). Employment assistance programs subsidize welfare recipients to leave the unemployment register by starting new ventures (Bendick and Egan, 1987). Taken together, these interventions often impose sizeable costs on the taxpayer. In the UK at the start of the new millennium, for example, the total cost of small business support amounted to $£ 7.9$ billion per annum, or 0.8 per cent of GDP (Storey, 2006).

Given these costs, the lack of robust evidence associating these policies with expanded levels of entrepreneurship is particularly striking. Part of the difficulty of evaluating entrepreneurship policies is that they may have very long run effects. For example, regional and national data suggest that some entrepreneurship outcomes, especially employment creation and venture growth, can take a decade and more to play out (Fritsch and Mueller, 2008; Carree and Thurik, 2008). These long-run effects are not accurately captured by conventional evaluations, which are usually performed a few years after the policies are implemented, and so capture only short-term impacts (Hart, 
2003). An important question therefore concerns the durability of shocks to entrepreneurship, whether these are "policy" shocks (derived from sudden changes to government policy) or "economic" shocks (derived from sudden changes to technology, for example).

At the heart of this question is whether entrepreneurship evolves as a trendstationary or as a non-stationary time-series process. If entrepreneurship is trendstationary, economic and policy shocks can be regarded as transitory from an aggregate perspective: the rate of entrepreneurship eventually reverts to its underlying, long-run ("natural”) rate. Granted, this "natural rate” might also shift over time; but then one would expect entrepreneurship to be stationary once structural breaks are allowed for. So if the rate of entrepreneurship is trend- (or broken trend-) stationary, entrepreneurship policy shocks will have only temporary effects at the aggregate level. If on the other hand the rate of entrepreneurship is non-stationary, such shocks will have permanent effects.

In a time-series context, hysteresis can be defined and measured in various ways. A popular approach in the empirical literature simply equates hysteresis with the existence of a unit root in a variable (see, Røed 1997, for a survey). An alternative approach proposed by Jaeger and Parkinson (1994) posits a more demanding criterion: hysteresis exists if cyclical changes affect the natural rate of a variable, even as the natural rate follows a unit root process. In which case, temporary shocks have permanent effects while the business cycle does not evolve independently of the natural rate; it then follows that a unit root is a necessary but not a sufficient condition for hysteresis. In this article, we adopt Jaeger and Parkinson's (1994) definition of hysteresis in order to conduct a searching test and to explore whether entrepreneurship exhibits cycles with potentially durable long-run effects.

To test for hysteresis in this way, we follow Jaeger and Parkinson (1994) and decompose entrepreneurship into two unobservable components: a non-stationary "natural rate” component, and a stationary "cyclical” component. These components can be estimated by maximum likelihood using the Kalman filter. Although Jaeger and Parkinson's approach has been applied extensively in the literature on unemployment (see Assarson and Janson, 1998; Karamé, 1999; Salemi, 1999; Di Sanzo and Pérez, 
2005; Logeay and Tober, 2005), to the best of our knowledge its application to entrepreneurship is novel.

The goal of the present paper is to explore whether aggregate rates of entrepreneurship exhibit persistence or hysteresis. We do so using quarterly time-series data on self-employment rates for Spain and the US. Different labor market structures and welfare systems mean that conditions for hysteresis might be systematically different in Europe compared with the US (Di Tella and MacCulloch, 2006; Raurich et al. 2006), so the comparative empirical perspective we take seems to be a natural one. We argue that if entrepreneurship exhibits hysteresis, then entrepreneurship policies might be more powerful than has been thought hitherto, since any increase in entrepreneurship brought about these policies are incorporated into all future levels of entrepreneurial activity. Furthermore, business cycles would have important effects on the real economy, by impacting on the future trajectory of an economy's natural rate of entrepreneurship.

This article has the following structure. The next section discusses in greater detail theory and evidence about persistence, hysteresis and business cycles in entrepreneurship. The third section describes the data and the estimation methodology. As is common in the literature, entrepreneurship is measured in terms of selfemployment rates. Self-employment is an important component of the labor market in many economies. Indeed, in most countries it comprises a larger portion of the workforce than unemployment does (Parker and Robson, 2004). The present inquiry therefore also adds to the labor economics literature on hysteresis, which has focused mainly on unemployment hitherto. ${ }^{1}$ The fourth section presents and discusses the results and performs a robustness check on the specification of the model. The final section concludes with a discussion of policy implications and some promising avenues for future research.

\footnotetext{
${ }^{1}$ A different strand of literature explores hysteresis in the realm of international trade and industrial structure: see Franz (1990), Dannenbaum (1998) and Campa (2004).
} 


\section{Persistence, hysteresis, business cycles and entrepreneurship}

Rates of entrepreneurship vary dramatically between countries but exhibit a fairly high degree of temporal stability (Parker and Robson, 2004). Individual-level panel data reveal that the best predictor of someone being self-employed in the next period is whether they are self-employed in the current period (Henley, 2004). This "state-dependence" property appears to aggregate up to the regional level. For example, Fritsch and Mueller (2007) explain more than one-half of the variance in German regional start-up rates in terms of regional start-up rates from 15 years earlier. The same property also holds at the national level, with several studies being unable to reject the null hypothesis of a unit root in self-employment rates (Parker, 1996; Cowling and Mitchell, 1997; Parker and Robson, 2004; Bruce and Mohsin, 2006).

What might explain these findings? At the individual level, there could be nonpecuniary costs of switching occupation, such as the sudden loss of a pleasant compensating differential, disruption to an accustomed lifestyle, or a stigma from failure (Gromb and Scharfstein, 2002; Landier, 2004). Alternatively, switching costs could be economic in nature involving, for example, lost sector-specific experience, costs of raising start-up capital (if entering entrepreneurship), or re-training costs (if entering paid-employment). Switching costs might also relate to exit barriers caused by incurring sunk costs of capital with limited resale value; prior commitments to customers; or a desire by entrepreneurs to avoid sending an adverse signal of ability by abandoning their ventures (Boot, 1992). In a different vein, Dixit (1989) shows that risk together with sunk costs can give agents an option value of waiting before switching occupation. This reduces the total amount of entry and exit that occurs - as conditions have to become very bad before entrepreneurs close their business and relinquish their sunk costs, or very favorable before they are willing to incur the risk of jeopardizing their assets by entering the market. Risk generates an "option value” of remaining in the present occupation and deferring a costly switch. Only when average incomes in entrepreneurship reach some upper "trigger point" will people become entrepreneurs. And they will only leave entrepreneurship in the presence of adjustment costs if incomes drop to some lower trigger point. Between these two trigger points individuals remain in their current occupation (Dixit and Rob, 1994). Dixit and Rob (1994) explicitly refer to this inertia in occupational choice as "hysteresis". 
At the more aggregated level, theoretical models of multiple entrepreneurship equilibria can explain why ostensibly similar regions and countries exhibit pronounced and enduring differences in entrepreneurship. Thus Landier (2004) studies a model in which serial entrepreneurs possess private information about their abilities which cannot be credibly revealed to banks. High-quality serial entrepreneurship is deterred in economies where the equilibrium cost of capital is high. The cost of capital is high precisely because there is little or no high-quality serial entrepreneurship. But high quality serial entrepreneurship becomes privately worthwhile in economies where the equilibrium cost of capital is low - which in turn justifies the low cost of capital. Another multiple equilibrium model, by Parker (2005), explains why different geographical areas can possess persistently different rates of entrepreneurship based on self-perpetuating human capital choices within regions which affect payoffs in entrepreneurship and in paid-employment, locking different occupational choice structures into place as stable equilibria.

However, a drawback of these theoretical models is that they are quite stylized. Fundamentally, we lack empirical evidence about whether shocks to entrepreneurship are persistent. As noted in the Introduction, we follow Jaeger and Parkinson (1994) by defining hysteresis as a process in which cyclical shocks affect the "natural rate" of the variable in question, which evolves as a unit root process. Because the relationship between business cycles and entrepreneurship is also of interest in its own right, the remainder of this section will discuss theoretical perspectives and empirical evidence on entrepreneurship and the business cycle.

In principle, entrepreneurship could evolve either pro- or anti-cyclically, depending on the balance of forces at work in the private sector of the economy. Rampini (2004) proposes a risk-based reason why the number of entrepreneurs is likely to be pro-cyclical. When shocks to the economy are favorable, productivity and wealth in entrepreneurship increase, making agents more willing to bear risk (via decreasing absolute risk aversion) and become entrepreneurs. In addition, anticipating greater returns in favorable states, entrepreneurs also supply higher levels of effort, reducing moral hazard problems and making lenders more willing to fund risky investment 
projects. When shocks are unfavorable, the opposite process occurs: wealth, investment and entrepreneurship all decline.

A dynamic externality inherent in innovation provides another reason why entrepreneurship and aggregate economic activity might follow similar cycles over time. Radical innovations increase economic activity directly, and frequently indirectly create opportunities for other, subsequent innovations, further increasing opportunities for entrepreneurship and greater economic activity. Because entrepreneurs do not internalize this dynamic externality when making their decisions to innovate and invest, the result is excessive volatility and pro-cyclicality of entrepreneurship, innovation and economic growth (Barlevy, 2007).

These arguments suggest that entrepreneurship is not only pro-cyclical but may also generate and accentuate business cycles. Other theoretical contributions ask whether recessions have a "cleansing" effect, by removing low quality enterprises from the market (Caballero and Hammour, 1994). However, because real wages fall in recessions, individuals with relatively low ability have incentives in bad times to enter entrepreneurship and so can reduce the average quality of the entrepreneur pool (Ghatak, Morelli and Sjöström, 2007). This might explain the emergence of worker cooperatives and other "marginal" enterprises in recessions, which dissolve in economic recoveries when conventional employment opportunities become more readily available (Ben-Ner, 1988; Pérotin, 2006). An alternative argument for counter-cyclicality of entrepreneurship relates to monetary policy, since the cost of capital tends to increase in booms and decrease in recessions, inducing exits in the former state and entries in the latter. A problem with this argument though is that aggregate market demand is also higher in booms and lower in recessions, which could dominate changes in the cost of capital in terms of occupational choice. The entrepreneurship literature has referred to these offsetting forces in terms of "recession push" and "prosperity pull” effects (Parker, 2009, chapter 4).

The available evidence suggests that venture formation rates and individual transitions into entrepreneurship are higher on average in good economic times and lower on average in bad ones (Audretsch and Acs, 1994; Grant, 1996; Carrasco, 1999). However, this evidence is rather informal in nature. It is based on estimates of the sign 
of time dummies in individual-level studies of occupational choice rather than being derived from careful analyses of time-series data. It will therefore be interesting to see whether the results obtained in the present paper, derived using a dynamic time-series estimation methodology, bear out these suggestive findings.

Finally, we would argue that previous entrepreneurship research seems to have overlooked an important distinction between different types of entrepreneurs. Entrepreneurs who hire external labor (“employers”) belong to a distinct group which could exhibit different cyclical behavior compared with entrepreneurs who work on their own (“own-account entrepreneurs”). Both types of entrepreneur are likely to benefit from higher demand (growth in national income). But employers who run larger ventures and so benefit from economies of scale are likely to gain the most from demand growth (Klepper, 1996). These entrepreneurs can scale up production and expand employment, bidding up wages which draw relatively low-value own-account entrepreneurs out of entrepreneurship and into paid-employment (Lucas, 1978). In which case, one might expect the number of employer entrepreneurs to increase relative to the number of own-account entrepreneurs, making cyclical effects positive for employer entrepreneurs and negative for own-account entrepreneurs. And to the extent that more favorable economic conditions improve opportunities for some own-account entrepreneurs as well, we might expect some own-account entrepreneurs to start hiring labor (Cowling et al, 2004), in which case they switch from own-account to employer status, and reinforce the positive cyclical effects for employers and the negative cyclical effects for the own-account group. Our empirical estimates below will shed light on these conjectures. 


\section{Data and Methodology}

\subsection{Data}

In common with most previous studies, entrepreneurship in this paper is defined in terms of self-employment, reflecting data availability at the time-series level (Parker, 2009). Our empirical analysis uses quarterly data on non-agricultural self-employment rates, for the US and Spain. Following previous authors, workers in the agricultural sector are excluded because this sector is structurally different from the rest of the economy. The self-employment rate, $\left(S_{t}\right)$, is defined as the share of the workforce that is self-employed in non-agricultural activities. Rates of employer self-employment $\left(E_{t}\right)$ and own-account self-employment $\left(O A_{t}\right)$ are defined as the number of employers and own-account workers respectively, divided by the workforce.

The US self-employment data are seasonally adjusted quarterly observations drawn from the Current Population Survey (CPS, US Bureau of Labor Statistics). The Spanish self-employment data are seasonally adjusted quarterly observations drawn from the Labor Force Survey (EPA, Spanish National Statistics Institute). Owing to data limitations, both samples start in 1987(II) and conclude in 2004(IV). It should be noted at the outset that the self-employed are categorized differently by the American CPS compared with the Spanish EPA - in a way which increases the share of workers classified as self-employed in Spain relative to the US. In the US, independent ownermanagers and directors of incorporated enterprises are classified as employees, while in Spain they are classified as employers. In addition, the Spanish data allow the researcher to distinguish between own-account workers and employers, whereas they cannot be separated in the US case. These differences arise because the Bureau of Labor Statistics only partially follows the standards set by the International Labor Organization. In the CPS, individuals are asked: "Were you employed by government, by a private company, a non-profit organization, or were you self-employed (or working in a family business)?” Persons who respond that they are self-employed are then asked: "Is this business incorporated?” Persons who respond “yes” are classified by BLS as wage and salary workers, on the basis that, legally, they are the employees of their own 
businesses. $^{2}$ In the Spanish EPA, workers are asked questions about their main job or business, including "Were you an employee or self employed?" If self-employed, the respondent was further asked whether they have any employees. Although the Spanish and American self-employment data rest on different definitions, it is still useful to compare results derived from them. The two countries lie at opposite ends of the spectrum in terms of how regulated their labor markets are (Bertola, Boeri and Cazes, 2000), so it will be interesting to see if the structure of entrepreneurship dynamics differs between them.

Finally, real GDP is denoted by $Y_{t}$. Data on Spanish real GDP are taken from the Quarterly National Accounts database while data on US GDP are taken from the US Department of Commerce. These data are seasonally adjusted and are expressed in 1995 prices and in billions of chained 2000 US dollars.

\subsection{Econometric Methodology}

Several macroeconomic studies equate hysteresis in a time series with a unit root process $^{3}$. Others argue that hysteresis arises when changes to the cyclical component of a time series, $S_{t}^{C}$, induce permanent changes in the "natural rate" of the series, $S_{t}^{N}$. This is different to a unit root process. To comprehend the different estimation strategies these approaches call for, decompose the series $S_{t}$ into the sum of its two (unobservable) components: the non-stationary natural rate component, $S_{t}^{N}$, and the stationary cyclical component, $S_{t}^{C}$ :

$$
S_{t}=S_{t}^{N}+S_{t}^{C}
$$

Now define the natural rate component as a random walk plus a term capturing a possible hysteresis effect:

$$
S_{t}^{N}=S_{t-1}^{N}+\beta S_{t-1}^{C}+\varepsilon_{t}^{N}
$$

\footnotetext{
${ }^{2}$ For a detailed explanation of self-employment measurement in the CPS, see Bregger (1996), Manser and Picot (1999), Karoly and Zissmopoulos (2004) or Hypple (2004)

${ }^{3}$ See Blanchard and Summers (1986). Layard et al. (1991) popularized the term "pure" hysteresis for describing the presence of a unit root in time series.
} 
where the $\beta$ coefficient measures, in percentage points, how much the natural rate increases if the economy experiences a cyclical self-employment rate increase of 1 percent. Evidently a unit root in the self-employment rate $S_{t}$ is a necessary but not sufficient condition for the existence of hysteresis since a unit root could be generated by an accumulation of shocks to the natural rate $S_{t}^{N}$ while at the same time $\beta=0$ (Røed, 1997). In contrast, there is hysteresis if $\beta>0$.

The specification of the model is completed by writing the cyclical component of the self-employment rate as a stationary second-order autoregressive process ${ }^{4}$ :

$$
S_{t}^{C}=\phi_{1} S_{t-1}^{C}+\phi_{2} S_{t-2}^{C}+\alpha \Delta Y_{t-1}+\varepsilon_{t}^{C}
$$

augmented with a term, $\alpha \Delta Y_{t-1}$, which relates cyclical self-employment to lagged output growth, where $Y_{t-1}$ is lagged real GDP ${ }^{5}$. This enables the relationship between the business cycle and entrepreneurship to be analyzed. The random shocks $\varepsilon_{t}^{N}$ and $\varepsilon_{t}^{C}$ are assumed to be mean-zero draws from the normal distribution with variance-covariance matrix $\Omega$; the state-space form of the model can be written as

$$
\begin{gathered}
S_{t}=\left(\begin{array}{lll}
1 & 1 & 0
\end{array}\right)\left(\begin{array}{c}
S_{t}^{N} \\
S_{t}^{C} \\
S_{t-1}^{C}
\end{array}\right) \\
\left(\begin{array}{c}
S_{t}^{N} \\
S_{t}^{C} \\
S_{t-1}^{C}
\end{array}\right)=\left(\begin{array}{ccc}
1 & \beta & 0 \\
0 & \phi_{1} & \phi_{2} \\
0 & 1 & 0
\end{array}\right)\left(\begin{array}{c}
S_{t-1}^{N} \\
S_{t-1}^{C} \\
S_{t-2}^{C}
\end{array}\right)+\left(\begin{array}{c}
0 \\
\alpha \\
0
\end{array}\right) \Delta Y_{t-1}+\left(\begin{array}{c}
\varepsilon_{t}^{N} \\
\varepsilon_{t}^{C} \\
0
\end{array}\right) \\
\Omega=\left(\begin{array}{ccc}
\sigma_{N}^{2} & 0 & 0 \\
0 & \sigma_{C}^{2} & 0 \\
0 & 0 & 0
\end{array}\right)
\end{gathered}
$$

To summarize, hysteresis is inferred if the coefficient $\beta$ is significantly different from zero, whereas pro- or anti-cyclical variation is inferred depending on

\footnotetext{
${ }^{4}$ We find that AR(2) processes for the cyclical component fit the data well for all time series considered. Detailed specification test results are available from the authors on request.

${ }^{5}$ Alternative estimates obtained by using unemployment rates instead of real GDP generated similar results and are available on request.
} 
whether the coefficient $\alpha$ is positive or negative, respectively. The coefficients of the model (4) - (6) are estimated by maximum likelihood using a Kalman filter.

A non-linear version of this model (4) through (6) can also be estimated, to take account of the possibility that entrepreneurship rates respond asymmetrically to the business cycle. For example, positive technology shocks might create valuable opportunities for innovative entrepreneurs which attract entrants into the industry. Yet if negative demand shocks to the broader economy leave innovative sectors unaffected, there may not be a pronounced negative impact on rates of entrepreneurship. More generally, there is a large body of evidence suggesting that macroeconomic time series exhibit nonlinear or asymmetric behavior over various phases of the business cycle.

When we talk about "positive" or "negative" shocks, we do so relative to some threshold level of GDP growth, $\tau$ (where $\tau$ is not necessarily zero). To explore whether asymmetries exist, we estimate a non-linear version of the unobserved components model. Specifically, we replace the state-space equation (5) with the Threshold Auto Regressive (TAR) specification

$$
\left(\begin{array}{c}
S_{t}^{N} \\
S_{t}^{C} \\
S_{t-1}^{C}
\end{array}\right)=\left(\begin{array}{ccc}
1 & \beta & 0 \\
0 & \phi_{1} & \phi_{2} \\
0 & 1 & 0
\end{array}\right)\left(\begin{array}{c}
S_{t-1}^{N} \\
S_{t-1}^{C} \\
S_{t-2}^{C}
\end{array}\right)+\left(\begin{array}{c}
0 \\
\alpha^{+} \\
0
\end{array}\right) I_{t}^{+} \Delta Y_{t-1}^{+}+\left(\begin{array}{c}
0 \\
\alpha^{-} \\
0
\end{array}\right) I_{t}^{-} \Delta Y_{t-1}^{-}+\left(\begin{array}{c}
\varepsilon_{t}^{N} \\
\varepsilon_{t}^{C} \\
0
\end{array}\right)
$$

where $I_{t}^{+}$and $I_{t}^{-}$are the Heaviside indicator functions such that:

$$
\begin{aligned}
I_{t}^{+} & =\left\{\begin{array}{l}
1 \text { if } \Delta Y_{t-1} \geq \tau \\
0 \text { if } \Delta Y_{t-1}<\tau
\end{array}\right. \\
I_{t}^{-} & =\left\{\begin{array}{l}
1 \text { if } \Delta Y_{t-1}<\tau \\
0 \text { if } \Delta Y_{t-1} \geq \tau
\end{array}\right.
\end{aligned}
$$

This model can be estimated via maximum likelihood using the Kalman filter, where $\alpha^{+}$ and $\alpha^{-}$are among the parameters to be estimated, and $\tau$ is obtained by grid search to minimize the residual sum of squares of the autoregressions. In this context a test for asymmetry becomes a test for linearity, i.e. a test for a single regime against the alternative of two regimes. The null hypothesis we are interested in is $H_{0}: \alpha^{+}=\alpha^{-}$. 


\section{Results}

This section presents the results in several stages. First, we test what Jaeger and Parkinson (1994) have characterized as a necessary but not sufficient condition for hysteresis, namely the existence of a unit root in the self-employment time-series. Because unit root tests are well-known, our discussion will be deliberately brief. Second, we estimate the linear unobserved components model outlined in the previous section, incorporating a unit root as a maintained hypothesis. This enables hysteresis to be tested directly and the existence of (symmetric) business cycle effects to be examined. The third subsection explores the possibility of asymmetric business cycle effects, by estimating the nonlinear TAR unobserved components model. The relaxation of linearity acts as one important robustness check on the results; another is performed in the fourth subsection, where a unit root is no longer imposed on the unobserved components model but instead is tested as a restriction of a free model parameter within a generalized unobserved components model.

\subsection{Unit root tests}

In order to test the hypothesis of non-stationarity, we apply the traditional Augmented Dickey-Fuller (ADF) test and a modified version of the Dickey-Fuller and Phillips-Perron tests proposed by Ng and Perron (2001). This consists of a class of modified tests, $\bar{M}$, with GLS de-trending of the data and use of the modified Akaike information Criteria to select the autoregressive truncation lag. Table 1 reports the results of Ng-Perron tests, $\bar{M} Z_{\alpha}^{G L S}$ and $\bar{M} Z_{t}^{G L S}$, originally developed in Stock (1999) with GLS de-trending of the data as proposed by Elliot et al. (1996). In addition, NgPerron proposed a similar procedure that corrects the problem associated with the standard Augmented Dickey Fuller test, $\bar{M} S B^{G L S}$ and $\overline{M P} T^{G L S}$. All test statistics formally examine the unit root null hypothesis against the alternative of stationarity. ${ }^{6}$

\footnotetext{
${ }^{6}$ Other unit root tests allow for the possibility of non-linear behavior: see Papell et al (2000), LeónLedesma and McAdams (2004), Camarero and Tamarit (2004) and Camarero et al (2006, 2008).
} 
Table 1

Unit Root Tests

\begin{tabular}{|c|c|c|c|c|c|c|c|}
\hline Variable & $\bar{M} Z_{\alpha}^{G L S}$ & $\bar{M} Z_{t}^{G L S}$ & $\bar{M} S B^{G L S}$ & $\bar{M} P T^{G L S}$ & $\begin{array}{c}\text { Lag } \\
\text { length }\end{array}$ & $A D F$ & $\begin{array}{c}\text { Lag } \\
\text { length }\end{array}$ \\
\hline \multicolumn{8}{|l|}{ Spain } \\
\hline Self-employment rate & $-2.505^{*}$ & $-0.848^{*}$ & $0.339 *$ & $8.554^{*}$ & 2 & $-0.651^{*}$ & 2 \\
\hline $\begin{array}{l}\text { Own-account workers } \\
\text { rate }\end{array}$ & $0.730^{*}$ & $0.434^{*}$ & 0.594* & $27.749 *$ & 2 & $-0.411 *$ & 2 \\
\hline Employers rate & $0.395^{*}$ & $0.433^{*}$ & $1.096^{*}$ & $72.343^{*}$ & 0 & $-1.747^{*}$ & 0 \\
\hline \multicolumn{8}{|l|}{$\underline{U S}$} \\
\hline $\begin{array}{l}\text { Self-employment rate } \\
\text { (Non-incorporated) }\end{array}$ & $-2.080 *$ & $-0.894^{*}$ & $0.430^{*}$ & $10.650 *$ & 0 & $-1.138 *$ & 0 \\
\hline \multicolumn{8}{|l|}{ Critical values } \\
\hline $1 \%$ & -13.8000 & -2.5800 & 0.17400 & 1.78000 & & -3.530 & \\
\hline $5 \%$ & -8.1000 & -1.9800 & 0.23300 & 3.17000 & & -2.905 & \\
\hline $10 \%$ & -5.7000 & -1.6200 & 0.27500 & 4.45000 & & -2.590 & \\
\hline \multicolumn{8}{|l|}{ Notes: } \\
\hline $\begin{array}{l}\text { Test statistics defined in the } \\
\text { values are tabulated in Ng \& } \\
\text { * Rejects null hypothesis at } 1 \\
\text { ** Rejects null hypothesis at } \\
\text { *** Rejects null hypothesis a }\end{array}$ & $\begin{array}{l}\text { ext. "Lag leng } \\
\text { erron (2001). } \\
\text { significance l } \\
\% \text { significance } \\
10 \% \text { siønifica }\end{array}$ & $\begin{array}{l}\text { h" refers to } \\
\text { vel. } \\
\text { level. }\end{array}$ & he lag length u & $\mathrm{d}$ in the $\bar{M}$ & dd ADF tes & , respective & The critic \\
\hline
\end{tabular}

The results in Table 1 show that the null hypothesis of non-stationarity cannot be rejected for each series, regardless of the test. However, it is well known that structural breaks in time-series can lead to spurious inferences of a unit root. To deal with this possibility, we employ the Zivot and Andrews (1992) minimum ADF-t(min-t) procedure. The min-t statistics reported in Table 2 show that the null hypothesis of a unit root in the time series still cannot be rejected for either country. This buttresses our conclusion that a unit root exists in the self-employment rates of both Spain and the US - and additionally, for each type of self-employment in Spain. As noted above, a unit root is a maintained assumption needed to test for Jaeger and Parkinson's notion of hysteresis. We test this notion of hysteresis now. 
Table 2

Unit Root Tests Allowing for Structural Breaks

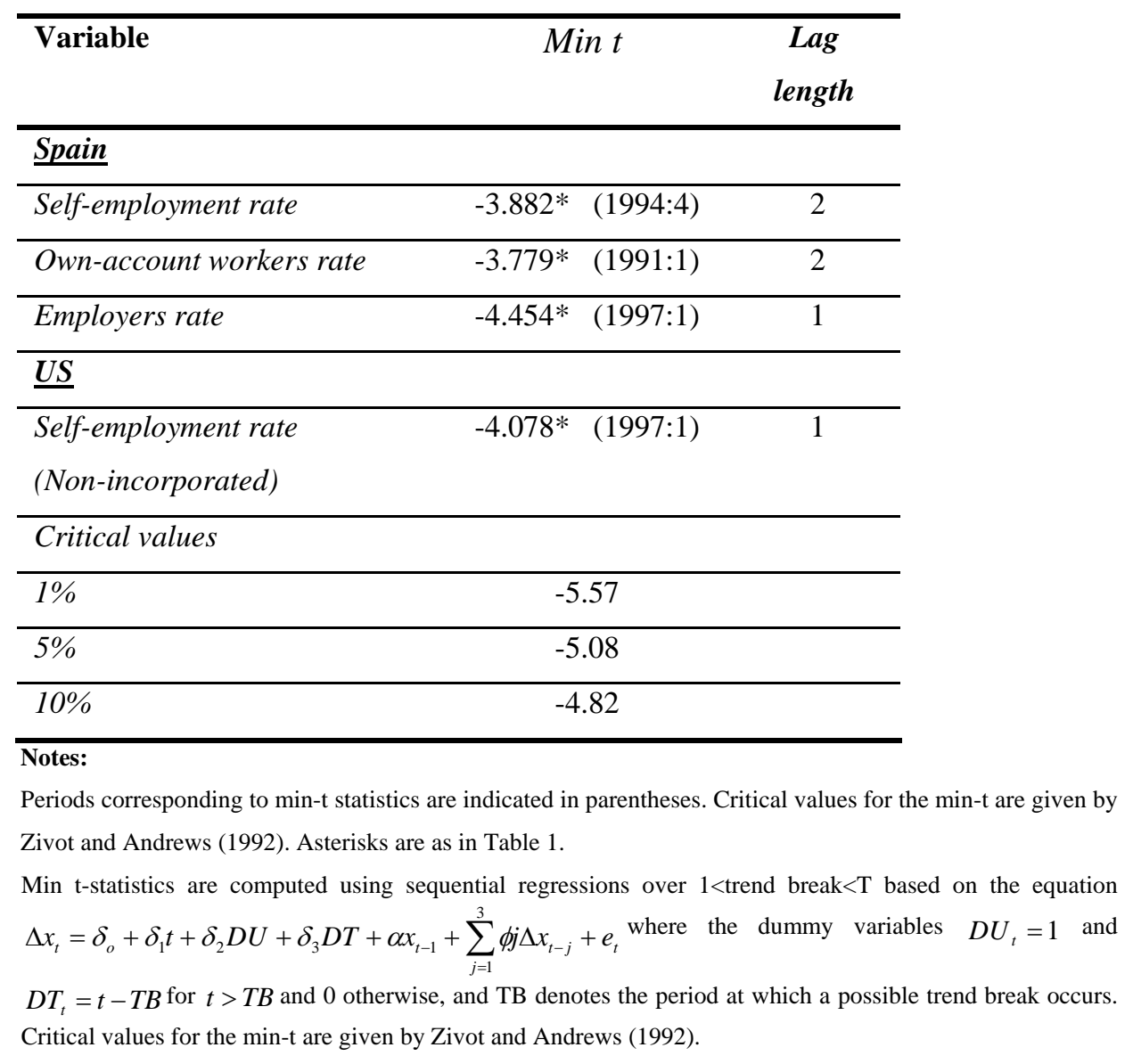

\subsection{The linear unobserved component model}

The first two columns of Table 3 present the results of estimating (4) through (6) for aggregate self-employment rates in the US and Spain, respectively. The parameter $\beta$ is positive in both countries, but is only statistically significantly different from zero in Spain. This implies that self-employment exhibits hysteresis in Spain. In particular, if the cyclical component of Spanish self-employment increases by 1\%, the natural rate of Spanish self-employment increases by $0.85 \%$. This is a numerically larger effect than Jaeger and Parkinson (1994) detected for Germany, the UK and Canada using unemployment data. Notably, Jaeger and Parkinson did not find evidence of hysteresis for US unemployment, either. It is unclear the extent to which these results reflect greater labor market imperfections and more generous public welfare systems in Europe compared with the US (Di Tella and MacCulloch, 2006; Raurich et al. 2006). 
Table 3

Estimates of the linear unobserved component model

\begin{tabular}{lllll}
\hline & US & & Spain & \\
\hline Natural rate equation & $\mathbf{S}$ & $\mathbf{S}$ & $\mathbf{E}$ & OA \\
\hline$\beta$ & 0.430 & $0.850^{*}$ & $0.560^{*}$ & $1.123^{*}$ \\
& $(0.335)$ & $(0.286)$ & $(0.214)$ & $(0.228)$ \\
\hline Cyclical rate equation & & & & \\
\hline$\phi_{1}$ & 0.502 & 0.367 & 0.007 & 0.096 \\
& $(0.324)$ & $(0.275)$ & $(0.006)$ & $(0.239)$ \\
\hline$\phi_{2}$ & -0.130 & $0.245^{* * *}$ & 0.002 & $0.220^{* *}$ \\
& $(0.127)$ & $(0.136)$ & $(0.003)$ & $(0.110)$ \\
\hline$\alpha$ & -0.007 & -0.013 & $0.035^{*}$ & $-0.048^{*}$ \\
& $(0.016)$ & $(0.017)$ & $(0.011)$ & $(0.015)$ \\
\hline$\sigma_{1}$ & 0.000 & 0.000 & $0.087^{*}$ & $0.003^{*}$ \\
& $(0.010)$ & $(0.022)$ & $(0.017)$ & $(0.000)$ \\
\hline$\sigma_{2}$ & $0.103^{*}$ & $0.135^{*}$ & 0.032 & $0.115^{*}$ \\
& $(0.010)$ & $(0.012)$ & $(0.034)$ & $(0.015)$ \\
\hline
\end{tabular}

Notes:

Standard errors are in parentheses. Asterisks are as in Table 1.

The effects of hysteresis are illustrated by the plots in Figures 1 and 2. These figures depict, for Spain and the US, respectively, the self-employment rate and the estimates of the natural rate and the cyclical component. In Spain, where evidence of pronounced hysteresis has been detected, the natural rate component of selfemployment follows quite closely the actual self-employment rate. By contrast in the US the natural rate of self-employment is rather more stable.

Drawing on our earlier conceptual discussion, we explore the Spanish data further by decomposing the aggregate self-employment rate into its two constituent parts, employer $(E)$ and own-account $(O A)$ self-employment. We do so in order to determine whether hysteresis is being driven by one or both of these elements. We then apply the unobserved components model (4) through (6) to each of these two constituent self-employment rates separately. The last two columns of Table 3 report the results. As can be seen, both components of Spanish self-employment exhibit hysteresis separately. Hysteresis seems to be more pronounced for the own-account selfemployment rate than for the employer self-employment rate, suggesting that rates of 
own-account self-employment are especially sensitive to cyclical shocks. Figures 3 and 4 illustrate the findings for each series.

The estimates of $\alpha$ reported in the fourth row of Table 3 suggest that neither the US nor the Spanish aggregate self-employment series $S_{t}$ exhibit a significant impact of business cycle variations in output on cyclical self-employment. However, separating out the aggregate self-employment series into its two components of employer and own-account self-employment generates an interesting finding which would otherwise be disguised: $\alpha$ becomes statistically significant, though with opposite signs, for both employers and own-account self-employees. The Spanish employer self-employment rate is pro-cyclical, but the own-account self-employment rate is anti-cyclical. These findings are consistent with our earlier conjectures that the most promising ownaccount self-employed switch to employer status in good times, while the least promising own-account workers are pulled into paid-employment as the demand for labor expands and employee wages rise.

\subsection{Asymmetries}

We next check whether our results are robust to the linear specification of the unobserved component model. This involves estimating the structure (4), (6) and (7) jointly, to determine whether there is a threshold for income growth which is associated with asymmetric business cycle responses. We wish to check whether the findings in the previous subsection are robust to possible asymmetries, or whether they were merely an artifact of a restrictive technical assumption of linearity.

Table 4 reports the results of estimating the non-linear TAR model. As before, no significant hysteresis is detected in the US. But in contrast to column 1 of Table 3, where symmetric US business cycle effects were insignificant, column 1 of Table 4 now identifies a significant asymmetric US business cycle effect, in which self-employment rates rise in recessions. This is the so-called "recession push" effect which has been extensively discussed in the entrepreneurship literature (Parker, 2009, chapter 4). The null hypothesis $H_{0}: \alpha^{+}=\alpha^{-}$is emphatically rejected: $\chi^{2}(1)=10.93(p<0.01)$. This highlights the importance of allowing for asymmetric business cycle effects in the US. 
Table 4

Non-Linear model estimation results

\begin{tabular}{|c|c|c|c|c|}
\hline & US & & Spain & \\
\hline Natural rate equation & $\mathbf{S}$ & $\mathbf{S}$ & $\mathbf{E}$ & $\mathbf{O A}$ \\
\hline \multirow[t]{2}{*}{$\beta$} & 0.325 & $0.504^{* * *}$ & $0.560 * *$ & 0.919* \\
\hline & $(0.326)$ & $(0.308)$ & $(0.250)$ & $(0.389)$ \\
\hline \multicolumn{5}{|l|}{ Cyclical rate equation } \\
\hline \multirow{2}{*}{$\phi_{1}$} & $0.441 * * *$ & $0.722 *$ & $0.086^{*}$ & 0.308 \\
\hline & $(0.326)$ & $(0.258)$ & $(0.012)$ & $(0.354)$ \\
\hline \multirow[t]{2}{*}{$\phi_{2}$} & -0.125 & 0.033 & 0.032 & 0.177 \\
\hline & $(0.177)$ & $(0.069)$ & $(0.027)$ & $(0.180)$ \\
\hline \multirow[t]{2}{*}{$\alpha^{+}$} & 0.010 & -0.008 & $0.030 * * *$ & $-0.040 * *$ \\
\hline & $(0.020)$ & $(0.022)$ & $(0.016)$ & $(0.020)$ \\
\hline \multirow[t]{2}{*}{$\alpha^{-}$} & $0.376 *$ & -0.021 & $0.047 * *$ & $-0.058 * *$ \\
\hline & $(0.111)$ & $(0.028)$ & $(0.020)$ & $(0.023)$ \\
\hline \multirow[t]{2}{*}{$\sigma_{1}$} & $0.063^{* *}$ & 0.000 & $0.091 *$ & 0.029 \\
\hline & $(0.029)$ & $(0.002)$ & $(0.024)$ & $(0.172)$ \\
\hline \multirow[t]{2}{*}{$\sigma_{2}$} & $0.069 * *$ & $0.135^{*}$ & 0.021 & $0.110^{*}$ \\
\hline & $(0.028)$ & $(0.012)$ & $(0.086)$ & $(0.051)$ \\
\hline$\tau$ & -0.005 & 0.012 & 0.012 & 0.012 \\
\hline
\end{tabular}

Notes: The estimates of $\tau$ are obtained by grid search methods; no standard error is available for this parameter.

The evidence for Spain, presented in the remaining columns of Table 4, reveals that hysteresis is still present when the non-linear specification is used, although the $\beta$ estimates are slightly smaller compared with the corresponding entries in Table 3 . Also as in Table 3, there are no significant business cycle effects for the aggregate selfemployment series $S_{t}$, although there continue to be positive ones for employers and negative ones for own-account workers. There is little evidence of business cycle asymmetry for either the $\mathrm{E}$ or OA series, with $\chi^{2}(1)=0.62$ and $\chi^{2}(1)=0.38$, respectively. Hence the results for Spain in particular appear to be fairly robust overall. 
Table 5

Extended linear model estimation results

\begin{tabular}{|c|c|c|c|c|}
\hline & US & & Spain & \\
\hline Natural rate equation & $\mathbf{S}$ & $\mathbf{S}$ & $\mathbf{E}$ & $\mathbf{O A}$ \\
\hline \multirow[t]{2}{*}{$\beta$} & 0.478 & $0.840^{*}$ & $0.550 * * *$ & $1.134^{*}$ \\
\hline & $(0.318)$ & $(0.292)$ & $(0.284)$ & $(0.290)$ \\
\hline \multirow[t]{2}{*}{$\delta$} & 0.996* & 0.999* & $1.002 *$ & $1.001 *$ \\
\hline & $(0.002)$ & $(0.003)$ & $(0.003)$ & $(0.004)$ \\
\hline \multicolumn{5}{|l|}{ Cyclical rate equation } \\
\hline \multirow{2}{*}{$\phi_{1}$} & $0.858^{*}$ & 0.372 & 0.000 & 0.104 \\
\hline & $(0.034)$ & $(0.281)$ & $(0.192)$ & $(0.280)$ \\
\hline \multirow[t]{2}{*}{$\phi_{2}$} & $-0.930 *$ & $0.247 * * *$ & 0.238 & 0.228 \\
\hline & $(0.038)$ & $(0.137)$ & $(0.198)$ & $(0.155)$ \\
\hline \multirow[t]{2}{*}{$\alpha$} & $0.053^{*}$ & -0.008 & $0.032 *$ & $-0.050^{*}$ \\
\hline & $(0.015)$ & $(0.022)$ & $(0.012)$ & $(0.019)$ \\
\hline \multirow{2}{*}{$\sigma_{1}$} & 0.093* & 0.000 & $0.091^{*}$ & 0.031 \\
\hline & $(0.013)$ & $(0.006)$ & $(0.019)$ & $(0.183)$ \\
\hline \multirow[t]{2}{*}{$\sigma_{2}$} & 0.000 & $0.135 *$ & 0.019 & 0.110 \\
\hline & $(0.000)$ & $(0.012)$ & $(0.069)$ & $(0.058)$ \\
\hline
\end{tabular}

\subsection{Robustness to the unit root restriction}

The estimation strategy so far has involved testing for a unit root, and having found one (Section 4.1) imposed it on the structure of the unobserved components model (see e.g. the top left element of the $3 \times 3$ matrix in (5)). This assumption can be relaxed in the following "extended" model, which tests the robustness of the Jaeger and Parkinson (1994) decomposition to the assumed random walk structure of the natural rate, as well as the robustness of the empirical estimates derived above. The space-state form of the linear model is as before, except (5) is now replaced by:

$$
\left(\begin{array}{l}
S_{t}^{N} \\
S_{t}^{C} \\
S_{t-1}^{C}
\end{array}\right)=\left(\begin{array}{ccc}
\delta & \beta & 0 \\
0 & \phi_{1} & \phi_{2} \\
0 & 1 & 0
\end{array}\right)\left(\begin{array}{l}
S_{t-1}^{N} \\
S_{t-1}^{C} \\
S_{t-2}^{C}
\end{array}\right)+\left(\begin{array}{c}
0 \\
\alpha \\
0
\end{array}\right) \Delta Y_{t-1}+\left(\begin{array}{c}
\varepsilon_{t}^{N} \\
\varepsilon_{t}^{C} \\
0
\end{array}\right)
$$


Table 6

Extended non-linear model estimation results

\begin{tabular}{|c|c|c|c|c|}
\hline & US & & Spain & \\
\hline Natural rate equation & $\mathbf{S}$ & $\mathbf{S}$ & $\mathbf{E}$ & $\mathbf{O A}$ \\
\hline \multirow[t]{2}{*}{$\delta$} & 0.998* & 0.999* & $1.002^{*}$ & $1.005^{*}$ \\
\hline & $(0.246)$ & $(0.003)$ & $(0.003)$ & $(0.004)$ \\
\hline \multicolumn{5}{|l|}{ Cyclical rate equation } \\
\hline \multirow{2}{*}{$\phi_{1}$} & $0.584 * *$ & $0.722^{*}$ & 0.001 & $0.590 * *$ \\
\hline & $(0.254)$ & $(0.219)$ & $(0.155)$ & $(0.234)$ \\
\hline \multirow{2}{*}{$\phi_{2}$} & -0.156 & 0.033 & 0.230 & 0.035 \\
\hline & $(0.179)$ & $(0.083)$ & $(0.187)$ & $(0.080)$ \\
\hline \multirow[t]{2}{*}{$\alpha^{+}$} & 0.019 & -0.006 & $0.031^{* *}$ & $-0.040 * * *$ \\
\hline & $(0.026)$ & $(0.023)$ & $(0.013)$ & $(0.024)$ \\
\hline \multirow[t]{2}{*}{$\alpha^{-}$} & $0.324 *$ & -0.018 & $0.037 * * *$ & $-0.070 *$ \\
\hline & $(0.123)$ & $(0.031)$ & $(0.021)$ & $(0.026)$ \\
\hline \multirow[t]{2}{*}{$\sigma_{1}$} & $0.068 *$ & 0.000 & $0.091 *$ & $0.097 *$ \\
\hline & $(0.019)$ & $(0.001)$ & $(0.020)$ & $(0.010)$ \\
\hline \multirow[t]{2}{*}{$\sigma_{2}$} & $0.058 *$ & $0.135^{*}$ & 0.021 & 0.050 \\
\hline & $(0.019)$ & $(0.012)$ & $(0.066)$ & $(0.029)$ \\
\hline$\tau$ & -0.005 & 0.012 & 0.012 & 0.012 \\
\hline
\end{tabular}

The state space form of the extended non-linear model is analogous and so is suppressed for brevity. Table 5 reports the estimation results for the extended linear model, while Table 6 reports the estimates of the non-linear version of the extended model where separate $\alpha^{+}$and $\alpha^{-}$coefficients as well as $\delta$ are jointly estimated.

Taking the US first, the results in column 1 of Table 5 show that the unit root hypothesis can be rejected in the specific context of the unobserved components model $(\delta \neq 1)$ - but that pro-cyclicality now becomes statistically significant $(\alpha>0)$. Hysteresis remains insignificant $(\beta \cong 0)$. In contrast, the unit root restriction is confirmed in the non-linear specification of the US self-employment rate, with similar results in column 1 of Table 6 to those of column 1 in Table 4.

For Spain, the extended model makes less difference to the results. Estimates of the hysteresis and business cycles parameters $\beta, \alpha$ and $\left(\alpha^{+}, \alpha^{-}\right)$in Tables 5 and 6 are qualitatively similar to those of Tables 3 and 4 where a unit root in the natural rates 
series was imposed, Indeed, the unit root assumption is not rejected for Spain anywhere in Tables 5 and 6. For Spain, $\beta$ remains statistically significant while $\alpha$ is again positive and significant for employers and negative and significant for own-account workers. Hence the results for Spain in particular appear to be robust to generalizing the autoregressive structure of the natural rate variable.

\section{Conclusions}

This paper estimated unobserved components models for the self-employment rate in two developed but otherwise rather different economies: Spain and the United States. Defining hysteresis in terms of the interdependent evolution of a non-stationary natural rate and a stationary cyclical component, thereby distinguishing hysteresis from natural rate shocks, the results provide robust evidence of hysteresis in Spain but not in the US. This implies that economic and/or policy shocks in Spain have permanent effects on rates of entrepreneurship. In view of the economic importance of entrepreneurship in modern economies, these results suggest that policy-makers need to take particular care when designing pro-entrepreneurship and macroeconomic stabilization policies - especially in Spain. In view of evidence that proentrepreneurship policies can have unintended negative as well as positive side-effects on entrepreneurial outcomes (Parker, 2009, chapter 15), the case for public interventions therefore needs to be very compelling, since they can have profound long-run effects. An essential tool policy-makers need to make informed judgments in this regard is detailed policy evaluations. Our results argue for the use of much longer time horizons in formal evaluation exercises than the few years which are commonly used to gauge entrepreneurship policy impacts.

Our results also shed new light on the important but somewhat neglected issue of business cycle effects on entrepreneurship. Although we found some evidence of procyclicality of entrepreneurship rates in Spain, deeper analysis showed that one should distinguish between own-account and employer components of self-employment. Employers comprise the minority of the self-employed in most countries, including Spain; but they are usually associated with greater economic value-added (Cowling et al, 2004). We found that in Spain employer self-employment rates evolve pro-cyclically whereas own-account self-employment rates evolve counter-cyclically. Therefore the 
quality as well as the quantity of entrepreneurship in Spain appears to evolve in a procyclical manner. Consequently, effective counter-recessionary economic policies at the macro level become essential for governments wishing to encourage high quality entrepreneurship in order to stimulate employment and innovation. This is of course a highly topical policy issue at the time of writing, when the world economy is in a recession and governments across the globe are looking at entrepreneurship as a creative response to the unfavorable economic conditions.

In contrast to Spain, our results based on US data point to weak or non-existent hysteresis and business cycle effects in entrepreneurship. This might reflect the different nature of institutional and economic conditions in the US compared with Spain. However, we cannot rule out the possibility that it might simply reflect data limitations, as the aggregate self-employment rate is defined more restrictively by the US statistical authorities. Further research is needed to determine whether it is different national and institutional conditions, or merely different data definitions, which explain the diverse findings. Future work might fruitfully apply the methodology used in this article to a broader range of countries, and should also seek to lengthen the length of the data series that are utilized. A "micro" look at the causal processes underlying entrepreneurial dynamics would be another natural extension of this paper, complementing our "macro" analysis of entrepreneurial dynamics. In the context of policy analysis, the impact of particular regulations or macro policies on entrepreneurial entry and longevity could be explored in detail, either within a case study or natural experiment framework. That might help unlock the deep causes of hysteresis and business cycle effects, which were detected in this article, but which deserve much more detailed micro-level analysis to bridge the micro-macro divide. 


\section{References}

Acs, Z.J. and Audretsch, D. B. (1990), Innovation and Small Firms, MIT Press, Cambridge MA.

Assarson, B. and Janson, P. (1998), “Unemployment Persistence: the case of Sweden”, Applied Economic Letters, 5 (1), pp. 25-29.

Audretsch, D. B. (2003), "Entrepreneurship policy and the strategic management of places”, in D.M. Hart (ed.), The Emergence of Entrepreneurship Policy, Cambridge University Press, Cambridge, pp. 20-38.

Audretsch, D. B. and Acs, Z.J. (1994), "New firm start-ups, technology and macroeconomics fluctuations”, Small Business Economics, Vol. 6, pp. 439-49.

Audretsch, D. B. and Keilbach, M. (2004), "Entrepreneurship capital and economic performance”, Regional Studies, Vol. 38, pp. 949-59.

Audretsch, D. B. and Keilbach, M. (2007), "The theory of knowledge spillover entrepreneurship”, Journal of Management Studies, Vol. 44, pp. 1242-54.

Barlevy, G. (2007), “On the cyclicality of research and development”, American Economic Review, Vol. 97, pp. 1131-64.

Baumol, W. J. (2007), “Small firms: why market-driven innovation can't get along without them”, Paper presented at IFN Conference, Stockholm, September.

Ben-Ner, A. (1988), "The life-cycle of worker-owned firms in market economies: a theoretical analysis”, Journal of Economic Behavior and Organization, Vol. 10, pp. 287-313.

Bendick, M. and Egan, M.L. (1987), “Transfer payment diversion for small business development: British and French experience”, Industrial and Labor Relations Review, Vol. 40, pp. 528-42.

Bertola, G., Boeri, T. and Cazes, S. (2000), "Employment protection in industrialized countries: The case for new indicators”, International Labor Review, Vol. 139, No. 1, pp.57-72.

Blanchard, O. J. and Summers, L. H. (1986), "Hysteresis and the European Unemployment Problem”, NBER Macroeconomics Annual Vol. 1, pp. 15-78.

Boot, A. (1992), "Why hang on to losers? Divestitures and takeovers", Journal of Finance, Vol. 47(4), pp. 1401-23.

Bregger, J.E. (1996), "Measuring Self-Employment in the United States", Monthly Labor Review, Vol. 119, pp. 3-9.

Bruce, D. and Mohsin, M. (2006), "Tax policy and entrepreneurship: new time series evidence”, Small Business Economics, Vol. 26, pp. 409-25.

Caballero, R.J. and Hammour, M.L. (1994), “The cleansing effect of recessions”, American Economic Review, Vol. 84, pp. 1350-68.

Camarero M. and Tamarit, C. (2004), "Hysteresis vs. natural rate of unemployment: new evidence for OECD countries”, Economics Letters, Vol. 84, pp. 413-17

Camarero M., Carrion-I-Silvestre, J.L. and Tamarit, C. (2006), “Testing for hysteresis in unemployment in OECD countries: new evidence using stationarity panel tests with breaks”, Oxford Bulletin of Economics and Statistics, Vol. 68, pp. 167-82.

Camarero M., Carrion-I-Silvestre, J.L. and Tamarit, C. (2008), "Unemployment hysteresis in transition countries: evidence using stationarity panel tests with breaks”, Review of Development Economics, Vol. 12, pp. 620-35

Campa, J.M. (2004), “Exchange rates and trade: how important is hysteresis in trade?”, European Economic Review, Vol. 48, pp. 527-48

Carrasco, R. (1999), "Transitions to and from self-employment in Spain: an empirical analysis”, Oxford Bulletin of Economics and Statistics, Vol. 61, pp. 315-41. 
Carree, M. and Thurik, A.R. (2008), "The lag structure of the impact of business ownership on economic performance in OECD countries”, Small Business Economics, Vol. 30, pp. 101-10.

Cowling, M. and Mitchell, P. (1997), “The evolution of UK self-employment: a study of government policy and the role of the macroeconomy”, Manchester School, Vol. 65, pp. 427-42.

Cowling, M., Mitchell, P. and Taylor, M. (2004), “Job creators”, Manchester School, Vol. 72, pp. 601-17.

Dannenbaum, J. (1998), "Hysteresis in foreign trade - a new empirical approach", Jahrbucher fur Nationalokonomie und Statistik, Vol. 217, pp. 589-612

Di Sanzo, S. and Pérez, A. (2005), "Unemployment and Hysteresis: a nonlinear unobserved components approach”. IVIE Working Papers, WP-AD 2005-34.

Di Tella, R. and MacCulloch, R. (2006), "Europe versus America: institutional hysteresis in a simple normative model”, Journal of Public Economics, Vol. 90, pp. 2161-86.

Dixit, A. (1989), "Entry and exit decisions under uncertainty”, Journal of Political Economy, Vol. 97, pp. 620-38.

Dixit, A. and Rob, R. (1994), "Switching costs and sectoral adjustments in general equilibrium with uninsured risk", Journal of Economic Theory, Vol. 62, pp. 48-69.

Elliott, U., Rothenberg, T. J. and Stock, J. H. (1996), "Efficient Tests for an Autoregressive Unit Root”, Econometrica 64, 813-836.

Franz, W. (ed.) (1990), Hysteresis Effects in Economic Models, Physica-Verlag, Heidelberg.

Fritsch, M. and Mueller, P. (2007), "The persistence of regional new business formation-activity over time - assessing the potential of policy promotion programs”, Journal of Evolutionary Economics, Vol. 17, pp. 299-315.

Fritsch, M. and Mueller, P. (2008), "The effect of new business formation on regional development over time: the case of Germany”, Small Business Economics, Vol. 30, pp. 15-29.

Ghatak, M., Morelli, M. and Sjöström, T. (2007), "Entrepreneurial income, occupational choice, and trickle up policies”, Journal of Economic Theory, Vol. 137, pp. 27-48.

Grant, D. (1996), "The political economy of new business formation across the American states, 1970-1985”, Social Science Quarterly, Vol. 77, pp. 28-42.

Gromb, D. and Scharfstein, D. (2002), “Entrepreneurship in equilibrium”, NBER Working Paper 9001, NBER, Cambridge MA.

Haltiwanger, J. (2006), “Entrepreneurship and job growth”, in D. B. Audretsch, R. Strom and Z. Acs (eds.), Entrepreneurship, Growth and Public Policy, Cambridge University Press, Cambridge.

Hart, D.M. (ed.) (2003), The Emergence of Entrepreneurship Policy, Cambridge University Press, Cambridge.

Henley, A. (2004), "Self-employment status: the role of state dependence and initial circumstances”, Small Business Economics, Vol. 22, pp. 67-82.

Hypple, S. (2004) "Self-employment in the United States: an update”, Monthly Labor Review, January/February, 24-47.

Jaeger, A. and Parkinson, M. (1994), "Some evidence on Hysteresis in Unemployment Rates”. European Economic Review 38, 329-42.

Karamé, F. (1999), “Unemployment persistence: the hysteresis assumption revisited”. Mimeo. EUREQua. 
Karoly L.A. and Zissmopoulos, J. (2004), "Self-Employment Trends and Patterns Among Older U.S. Workers”. Monthly Labor Review, 24-47.

Klepper, S. (1996), "Entry, exit, growth and innovation over the product life cycle", American Economic Review, Vol. 86, pp. 562-83.

Landier, A. (2004), "Entrepreneurship and the stigma of failure”, Mimeo, Stern School of Business, New York University.

Layard, R., Nickell, S. and Jackman, R. (1991), Unemployment, Macroeconomic Performance and the Labor Market. Oxford University Press, Oxford.

León-Ledesma, M. and P. McAdam, (2004) "Unemployment, Hysteresis and Transition,” Scottish Journal of Political Economy 51, pp.1-24.

Lerner, J. (1999), "The government as venture-capitalist: the long-run impact of the SBIR program”, Journal of Business, Vol. 72, pp. 285-318.

Logeay, C. and Tober, S. (2005), "Hysteresis and Nairu in the Euro Area". IMK, Germany, WP 4/2005.

Lucas, R. E. (1978), “On the size distribution of business firms”, Bell Journal of Economics, Vol. 9, pp. 508-23.

Manser, M.E., and Picot, G. (1999), “The role of self-employment in U.S. and Canadian job growth”, Monthly Labor Review, April, 1999, pp.10-25

Ng, S., Perron, P. (2001), "Lag length selection and the construction of unit root tests with good size and power”, Econometrica, 69, pp. 1529-54.

Papell, D., Murray, C., and Ghiblawi, H. (2000), "The Structure of Unemployment," The Review of Economics and Statistics 82, 2000, pp.309-15.

Parker, S.C. (1996), "A time series model of self-employment under uncertainty", Economica, Vol. 63, pp. 459-75.

Parker, S.C. (2005), "Explaining regional variations in entrepreneurship as multiple occupational equilibria”, Journal of Regional Science, Vol. 45, pp. 829-50.

Parker, S.C. (2009), The Economics of Entrepreneurship, Cambridge University Press, Cambridge.

Parker, S. C. and Robson, M.T. (2004), "Explaining international variations in selfemployment: evidence from a panel of OECD countries", Southern Economic Journal, Vol. 71, pp. 287-301.

Pérotin, V. (2006), "Entry, exit and the business cycle: are cooperatives different?" Journal of Comparative Economics, Vol. 34, pp. 295-316.

Rampini, A. A. (2004), "Entrepreneurial activity, risk and the business cycle”, Journal of Monetary Economics, Vol. 51, pp. 555-73.

Raurich, X., Sala, H. and Sorolla, V. (2006), "Unemployment, growth, and fiscal policy: new insights on the hysteresis hypothesis”, Macroeconomic Dynamics, Vol. 10, pp. 285-316.

Røed, K. (1996), "Unemployment hysteresis - macro evidence from 16 OECD countries”, Empirical Economics, Vol. 21, pp. 589-600.

Røed, K. (1997), “Hysteresis in Unemployment”, Journal of Economic Surveys, Vol. 11, pp. 389-418.

Røed, K. (2002), "Unemployment hysteresis and the natural rate of vacancies", Empirical Economics, Vol. 27, pp. 687-704.

Salemi, M.K. (1999), "Estimating the natural rate of unemployment and testing the natural rate hypothesis”, Journal of Applied Econometrics, 14 (1), 1-25.

Stel, A. van, Carree, M. and Thurik, A.R. (2005), "The effect of entrepreneurial activity on national economic growth”, Small Business Economics, Vol. 24, pp. 311-21. 
Stock, J.H. (1999), A class of tests for intregration and cointegration. In: Engle, R.F., White, H. (Eds.), Cointegration, causality and forecasting. A festschrift in honour Clive W.J. Granger. Oxford University Press, Oxford, 135-167.

Storey, D.J. (2006), "Evaluating SME policies and programmes: Technical and political dimensions”, in M. Casson, B. Yeung, A. Basu and N. Wadeson (eds.), The Oxford Handbook of Entrepreneurship, Oxford University Press, Oxford, pp. 248-78,

Zivot, E. and Andrews, D. W. K. (1992), "Further Evidence on the Great Crash, the OilPrice Shock and the Unit Roof Hypothesis", Journal of Business and Economics Statistics, Vol. 10, pp. 251-270. 
Figure 1

Actual, Natural and Cyclical self-employment rates, Spain
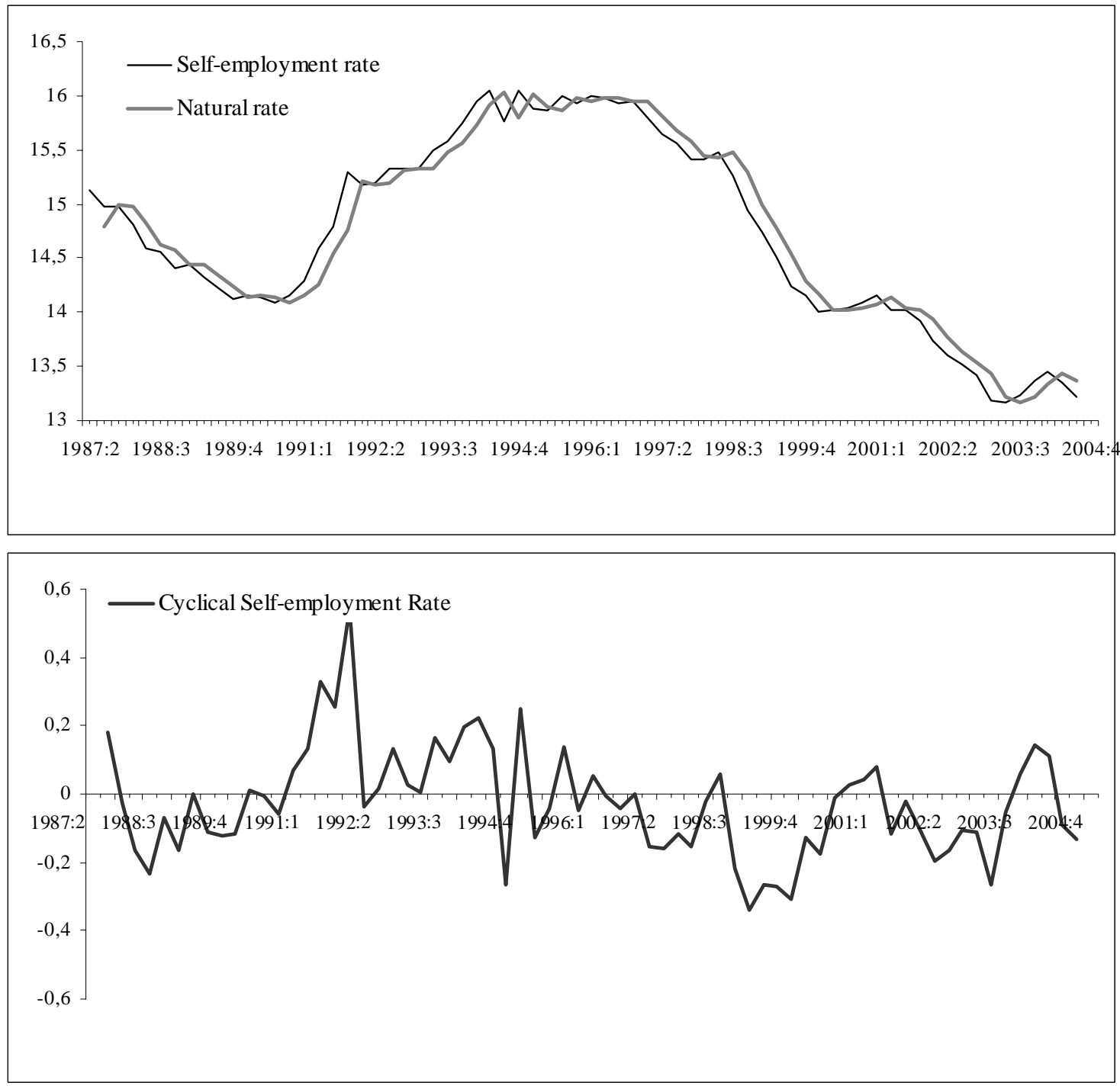
Figure 2

Actual, Natural and Cyclical self-employment rates, US
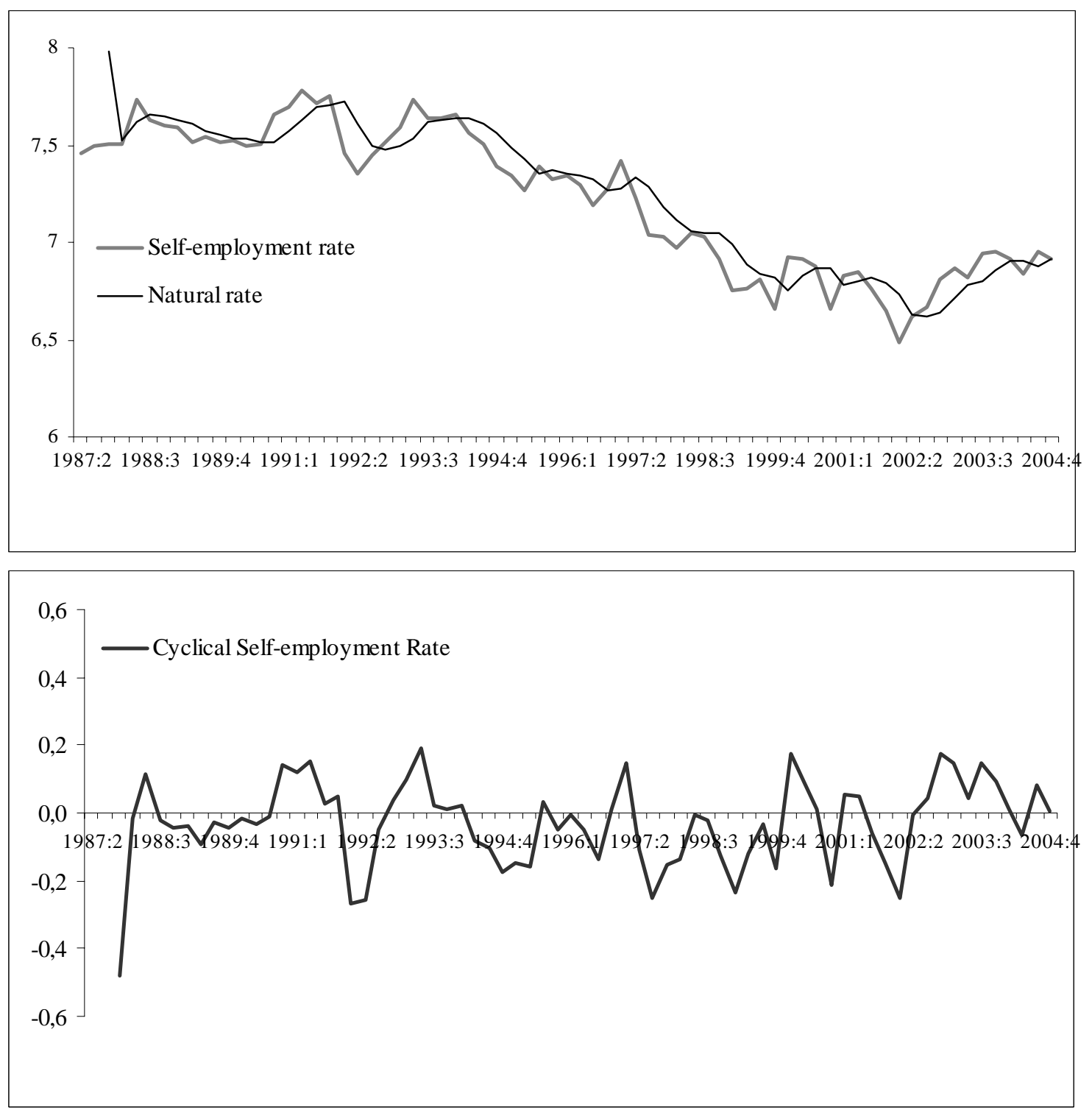
Figure 3

Actual, Natural and Cyclical Employers rates, Spain
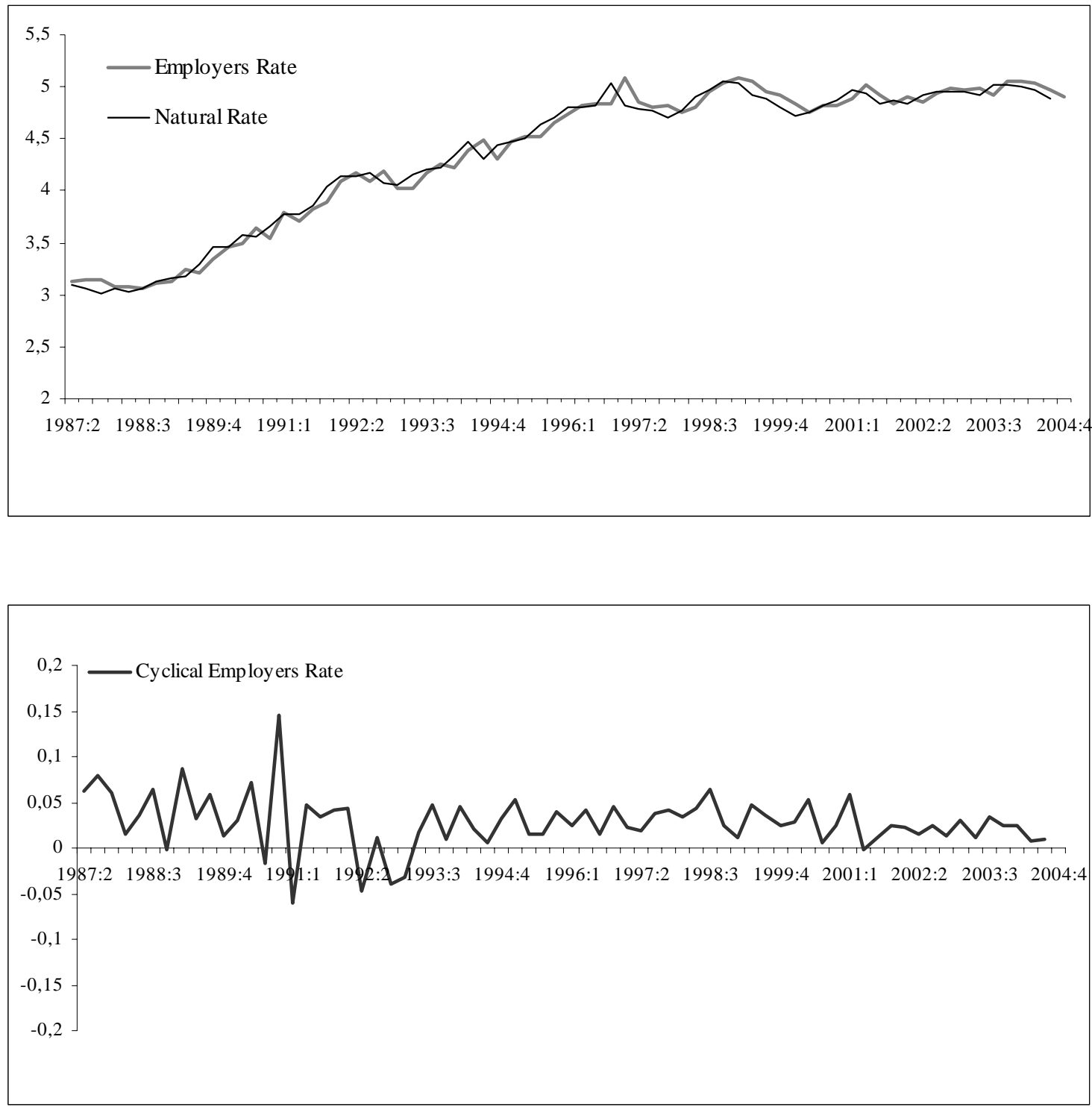
Figure 4

Actual, Natural and Cyclical Own-account workers rates, Spain
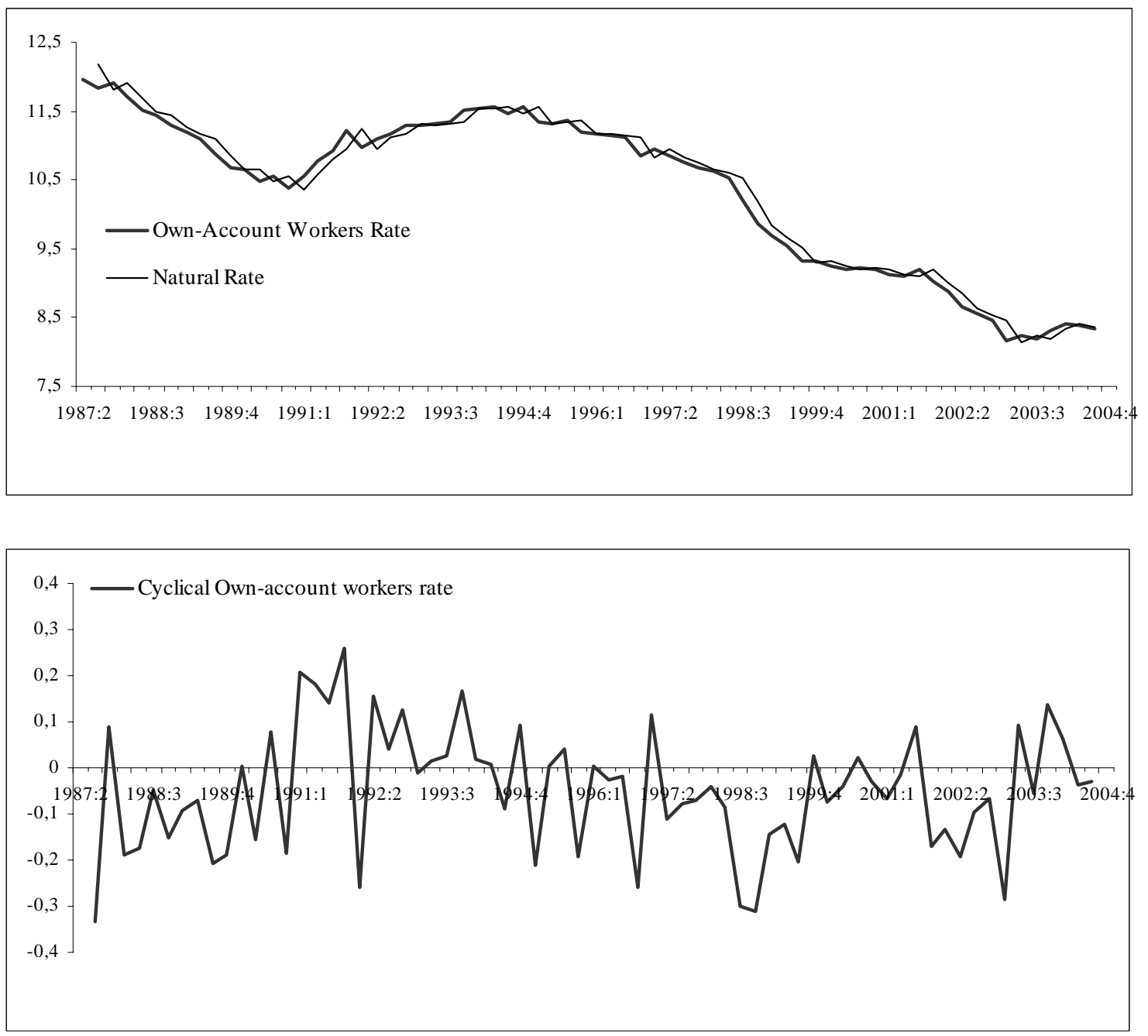